\title{
BAG4 wt Allele
}

National Cancer Institute

\section{Source}

National Cancer Institute. BAG4 wt Allele. NCI Thesaurus. Code C52466.

Human BAG4 wild-type allele is located in the vicinity of $8 p 12$ and is approximately $37 \mathrm{~kb}$ in length. This allele, which encodes BAG family molecular chaperone regulator 4 protein, plays a role in the regulation of apoptosis through the suppression of both tumor necrosis factor receptor signaling and protein chaperone function. 